\title{
HUBUNGAN NEGARA-UMMAH \\ DALAM HUKUM INDONESIA DAN ISLAM
}

\author{
M. Nurkholis Al-Amin \\ FAI-UCY \\ kholisnujib@gmail.com
}

\section{Nurjidin}

FAI-UCY

\begin{abstract}
Through legal references review, the present study aimes at finding out the concept of ummah in the Medinah Charter and the concept of nation state in the Jakarta Charter (Indonesia's 1945 Constitution) along with the correlation between the two. The conclusion is that, as constitution, the Medinah Charter is as sililar as the Jakarta Charter or the 1945 Constitution in the context of Indonesia, which has a feature of equations. From the historical point of view, both were grew out of a plural society which then formed a whole community in one melting pot, that is governance or state. In its values, both contains the recognition of plurality of society and the principles of equality, unity, justice in one community.
\end{abstract}

Keywords: State, ummah, law, Indonesia, Islam

Abstrak: Melalui kajian referensi hokum, telaah ditujukan untuk mengetahui konsep ummah dalam Piagam Madinah dan Negara Bangsa dalam Piagam Jakarta (UUD 1945) beserta korelasi antara keduanya dalam hubungannya. Kesimpulannya adalah Piagam Madinah sebagai konsitusi dalam konteks Indonesia adalah Piagam Jakarta atau UUD 1945, yang mempunyai corak persamaan. Dari segi historisnya, bahwa keduanya tumbuh dari dari komunitas yang majemuk yang kemudian membentuk suatu komunitas yang utuh dalam satu wadah, yakni suatu negara. dalam nilai-nilainya terkandung tentang pengakuan kemajemukan masyarakat dan prinsip-prinsip persamaan, persatuan, keadilan dalam komunitas yang satu.

Kata kunci: Negara, ummah, hokum, Indonesia, Islam

\section{A. Pendahuluan.}

Sembodo menyatakan belakangan ini, isu tentang peta politik serta bentuk-bentuk intelektual dan praktik pelembagaan hukum Islam makin menguat dan menentukan sehingga antusiasme dan kesadaran Syari'ah melanda hampir seluruh dunia Islam. ${ }^{1}$

Bahkan, pertumbuhan dan perkembangan agama itu bersama

${ }^{1}$ Cipto Sembodo, "Dari Khilafah Ke Nation-States: Transformasi Hukum Islam Era Modern," Ulumuddin 6, no. 2 (2016): 136-150. 
dengan pertumbuhan dan perkembangan sistem politik yang diilhaminya. ${ }^{2}$ Sejak Rasulullah saw melakukan hijrah dari Makkah ke Yastrib-yang kemudian diubah namanya menjadi Madinah-hingga saat sekarang ini dalam wujud sekurang-kurangnya kerajaan Saudi Arabia dan Republik Islam Iran, Islam menampilkan dirinya sangat terkait dengan masalah kenegaraan. 3 Dengan demikian, ketika membahas tentang Negara (Indonesia), maka juga tidak akan terlepas dari suatu sistem hukum yang berlaku pada Negara tersebut, baik dari sistem Hukum tata negaranya ataupun hukum administrasi negara tersebut. Di samping itu, hubungan antara umat atau masyarakat dengan pemimpin atau pemerintah merupakan hal yang mempunyai keterkaitan yang sangat erat dalam suatu negara.

Negara terbentuk dari kumpulan umat atau masyarakat, dan keluarga merupakan suatu komunitas terkecil dalam suatu negara. 4 keluarga pada masyarakat arab tercermin dari keberadaan suku-suku ataupun bentuk bani yang mana merupakan suatu bentuk golongangolongan yang mempunyai pemimpinnya sendiri-sendiri. Sedangkan di Indonesia, yang dahulunya dikenal dengan nama nusantara, tidak terlepas dari keberadaan beberapa suku yang berbeda-beda, sebagaimana kita ketahui kejayaan kerajaan Majapahit dengan patih Gajahmada-nya yang menginginkan untuk bersatunya nusantara secara utuh dengan Sumpah Palapa-nya yang termashur itu. Selanjutnya lahirnya negara Indonesia sendiri pun juga tidak terlepas dari keberagaman masyarakat pendukungnya. Sebagai Negara yang notabene masyarakatnya beragama Islam, maka mengkaji sisi historitas kenabian dalam menghubungkan antara politik dengan Islam merupakan hal yang menarik. Oleh karena itu, dalam makalah ini akan menelaah konsep ummah dalam Piagam Madinah dan Negara Bangsa dalam Piagam Jakarta (UUD-45) beserta korelasi

${ }^{2}$ M. Nur Kholis Al Amin and Difla Nadjih, "Tinjauan Pustaka Diskursus Politik Islam," Jurnal Ulumuddin 4, no. 2 (2014): 71-77.

3Nurcholis Madjid, "Agama dan Negara dalam Islam: Telaah Atas Fiqh Siyasi Sunni," dalam Islam Universal (Pustaka Pelajar, 2007), h. 202.

4 Andrie Irawan, "Posisi Hukum Agama (Hukum Islam) Dalam Ranah Politik Indonesia," Academy Of Education Journal Pendidikan Pancasila dan Kewarganegaraan 6, no. 1 (2015): 65-73. 
antara keduanya dalam hubungannya dengan konsep ummah dan negara bangsa.

\section{B. Awal Lahirnya Negara dan Negara Madinah.}

Negara dalam kamus ilmiah mempunyai definisi wilayah yang memiliki kedaulatan dan pemerintahan. 5 Jauh sebelum masehi sudah di kenal dengan keberadaan negara, dimana zaman dahulu identik dengan suatu pemerintahan dengan sistem kerajaan, hal ini dapat diketahui dengan keberadaan hukum tertulis yang mana merupakan suatu tata aturan tertulis untuk rakyat (masyarakat/ umat) nya, yakni dengan hukum tertulis untuk pertama kalinya dalam sejarah adalah hukum Hamurabi, pada zaman kerajaan Babilonia, Irak, pada sekitar tahun 1950 SM. ${ }^{6}$ Di samping itu pada zaman Yunani kuno 300 SM juga terlahir negara hukum yang dipelopori oleh Aristoteles, ia menyatakan bahwa yang memerintah dalam negara bukanlah manusia, melainkan pikiran yang adil. Ini artinya, keadilanlah yang memerintah dan keadilan harus terjelma dalam kehidupan bernegara. 7

Dengan demikian, dapat dikemukaan bahwa konsep negara sudah terlahir sejak zaman sebelum masehi, hal ini mengindikasikan pula bahwa tatanan masyarakat atau rakyat juga sudah lahir seiring dengan lahirnya negara tersebut. Relevansi negara sebagaimana di atas, terhadap Piagam madinah, bahwasannya peradaban pada zaman Nabi di Madinah, Nabi membuat perjanjian di antara suku-suku yang ada di sana yang menghasilkan konstitusi tertulis pertama dalam sejarah umat manusia, Piagam Madinah (The Charter of Medina). Berdasarkan pasal pertama konstitusi tersebut, nabi membentuk ummah-yang disepakati oleh empat macam komunitas:Yahudi, Nasrani, Anshar, dan Muhajir-yakni negara persemakmuran. ${ }^{8}$ Lebih lanjut, pasal-pasal yang merupakan esensi penting dalam perjanjian tersebut bagi kehidupan "politik" kaum

5 Achmad Maulana dkk, Kamus Ilmiah Populer (yogyakarta: Absolut, 2003), $h$. 342.

6Bambang Sutiyoso, Metode Penemuan Hukum: Upaya Mewujudkan Hukum Yang Pasti dan Berkeadilan (yogyakarta: UII Press, 2002), h. 54.

7 Siti Fatimah, Praktik Judicial Review di Indonesia (yogyakarta: Pilar Media, 2005), h. 24.

8M. Abdul Karim, Sejarah Pemikiran dan Peradaban Islam (yogyakarta: Pustaka Book Publisher, 2009), h. 67. 
muslimin di antaranya adalah sebagai berikut:

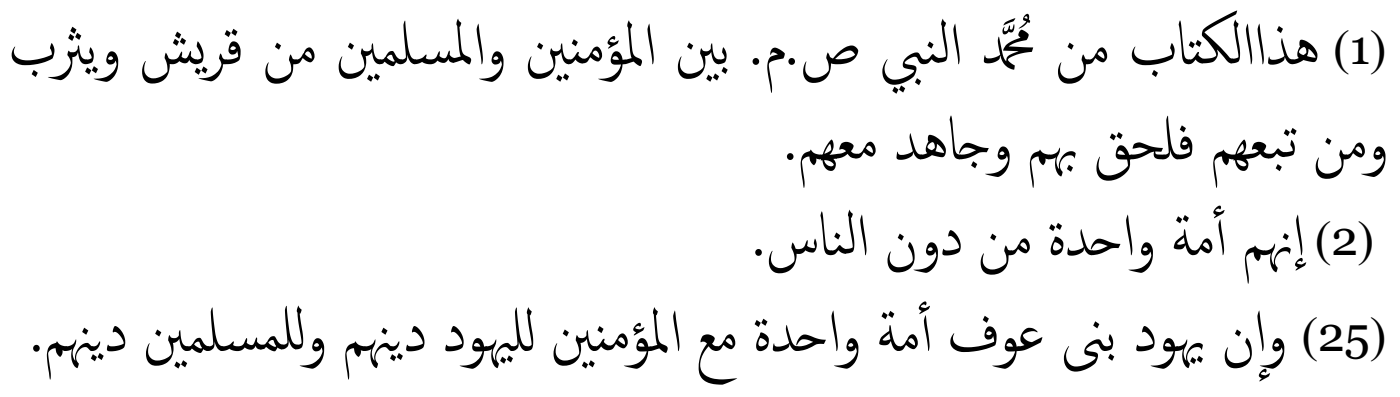

Dengan melihat esensi konstitusi tersebut secara politis, maka dapat ditarik suatu kesimpulan bahwasannya pada zaman Nabi ini, terlahirlah Negara madinah dengan komunitas ummahnya yang beragam. Negara Madinah pimpinan Nabi itu, seperti dikatakan oleh Robert Bellah, seorang ahli sosiologi agama terkemuka, adalah model bagi hubungan agama dan negara dalam Islam. Muhammad Arkoun, salah seorang pemikir Islam kontemporer terdepan, menyebut usaha Nabi Muhammad itu sebagai Eksperimen Madinah.

Ide pokok eksperimen Madinah oleh Nabi adalah adanya suatu tatanan sosial-politik yang diperintah tidak oleh kemauan pribadi, melainkan secara bersama-sama; tidak oleh prinsip-prinsip ad hoc yang dapat berubah-ubah sejalan dengan kehendak pemimpin, melainkan oleh prinsip-prinsip yang dilembagakan dalam dokumen kesepakatan dasar semua anggota masyarakat, yaitu sebuah konstitusi, ${ }^{9}$ yang dikalangan para sarjana modern juga menjadi amat terkenal sebagai "Konstitusi Madinah" atau "Piagam Madinah (Mitsāq al-Madīnah)".

\section{Konsep Ummah dalam Piagam Madinah}

\section{Relevansi konsep Ummah dalam al-Qur'an dengan Piagam Madinah}

Al-Qur'an bagi kaum muslimin merupakan sumber ajaran dalam kehidupannya, baik di dalam kehidupan pribadi dengan sang Khāliq ataupun kehidupan antar sesama manusia, dan hubungan manusia dengan komunitasnya, baik dari tingkat bawah (desa) sampai pada tingkat atas (negara). Namun, bagi sebagian pemikir Islam, seperti M. Abīd Al-

9Madjid, “Agama dan Negara dalam Islam: Telaah Atas Fiqh Siyasi Sunni,” h. 
Jābirī menegaskan bahwa tidak ada alasan kuat untuk mengatakan bahwa Rasulullah bertujuan untuk menciptakan sebuah negara dan tidak ada sesuatu pun di dalam al-Qur'an yang mengindikasikan bahwa ajaran Islam mengimplikasikan pembentukan sebuah negara. Namun, disisi lain, alQuran mengandung perintah-perintah yang sebagiannya hanya dapat dilaksanakan dengan otoritas yang mapan. Dengan kata lain, negara telah hadir sejak wafat Rosulullah sebagai sarana yang tak terpisahkan bagi pencapaian tujuan-tujuan umat Islam. ${ }^{10}$ Adapun konsep "ummah" di dalam al-Qur'an sebagaimana disebutkan dibeberapa ayat, seperti di dalam al-Baqarah (2):143, al-Baqarah (2):213, al-Māidah (5): 110,11 sehingga sebenarnya Al-Qur'an menyebut dengan jelas ummat kaum beriman, tetapi tidak mengajukan apa pun berkaitan dengan organisasi politik mereka. ${ }^{12}$ Sehingga, dapat dianalisa bahwasannya korelasi yang dimaksudkan oleh piagam madinah dalam konsep ummah tidak hanya sebatas dari cakupan كان الناس أمة واحدة,yang terdapat secara eksplisit yang disebutkan dalam al-Qur'a, yakni umat yang satu dalam satu wadah Islam, akan tetapi lebih dari itu, konsep ummah dalam piagam madinah adalah merujuk pada QS al Hujurāt ayat 13:

Hai manusia, Sesungguhnya Kami menciptakan kamu dari seorang laki-laki dan seorang perempuan dan menjadikan kamu berbangsa - bangsa dan bersuku-suku supaya kamu saling kenal-mengenal. Sesungguhnya orang yang paling mulia diantara kamu disisi Allah ialah orang yang paling taqwa diantara kamu. Sesungguhnya Allah Maha mengetahui lagi Maha Mengenal.

\section{Latar belakang konsep ummah dalam piagam madinah dan Nilai-nilai Dasarnya.}

Umat Islam memulai hidup bernegara setelah Nabi hijrah ke Yathrib, yang kemudian berubah nama menjadi Madinah. Di Yatsrib atau Madinahlah untuk pertama kali lahir satu komunitas Islam yang bebas dan merdeka di bawah pimpinan Nabi, dan terdiri dari para pengikut Nabi

${ }^{10}$ Abdou Filali Ansary, Pembaruan Islam; Dari Mana dan Hendak Kemana? (Bandung: Mizan, 2009), h. 148-155.

${ }^{11}$ N.A Baiquni dkk, Indeks Al-Qur'an: Cara Mencari Ayat al-Qur'an (Surabaya: Arloka, 1996), h. 346.

12Ibid. 150 . 
yang datang dari Makkah (Muhajirin) dan penduduk Madinah yang telah memeluk Islam, serta yang telah mengundang Nabi untuk hijrah ke Madinah (Anshar). Tetapi umat Islam dikala itu bukan satu-satunya komunitas di Madinah. Di antara penduduk Madinah terdapat juga komunitas-komunitas lain, yaitu orang-orang Yahudi dan sisa suku-suku Arab yang belum mau menerima Islam dan masih tetap memuja berhala. Dengan kata lain umat Islam di Madinah merupakan bagian dari suatu masyarakat majemuk.

Tidak lama setelah Nabi menetap di Madinah, atau menurut sementara ahli sejarah belum cukup dua tahun dari kedatangan Nabi di kota Madinah, beliau mempermaklumkan satu piagam yang mengatur kehidupan dan hubungan antara komunitas-komunitas yang merupakan komponen-komponen masyarakat yang majemuk di Madinah. Piagam tersebut lebih dikenal sebagai Piagam Madinah. ${ }^{13}$

Adapun di antara isi dari Piagam Madinah tersebut menegaskan bahwa "kaum Muslimin adalah umat yang bersatu utuh, mereka hidup berdampingan dengan kelompok-kelompok yang lain". Kelompokkelompok tersebut sebagaimana yang disebut dalam Piagam Madinah di antaranya adalah kelompok Muhajirin, Bani 'Auf, Bani Al-Harits, Bani Sa'idah, Bani Jusyam, Bani An-Najjar, Bani 'Amr bin 'Auf, Bani An-Nabit, Bani Al-Aus, Bani Tsa'labah, Bani Syutaibah.

Dari beberapa kelompok tersebut-dalam Piagam Madinahdiwakili oleh tiga kelompok besar, yakni kaum Muslim, orang arab yang belum masuk Islam, dan kaum Yahudi. Mereka dalam Piagam Madinah, menyepakati perjanjian, yaitu sebagai berikut:

1) Tiap kelompok dijamin kebebasannya dalam beragama

2) Tiap kelompok berhak menghukum anggota kelompoknya yang bersalah.

3) Tiap kelompok harus saling membantu dalam mempertahankan Madinah, baik yang muslim maupun yang non-muslim.

4) Penduduk Madinah semuanya sepakat mengangkat Muhammad

13Munawir Sjadzali, Islam dan Tata Negara: Ajaran, Sejarah, dan Pemikiran (Jakarta: UI-Press, 1993), h. 9-10. 
sebagai pemimpinnya dan memberi keputusan hukum segala perkara yang dihadapkan kepadanya.

5) Meletakkan landasan berpolitik, ekonomi, dan kemasyarakatan bagi negeri Madinah yang baru terbentuk.

Dasar berpolitik negeri Madinah adalah prinsip keadilan yang harus dijalankan kepada setiap penduduk tanpa pandang bulu. Dalam prinsip keadilan diakui adanya kesamaan derajat antara manusia yang satu dengan manusia yang lain. Yang membedakan di antara mereka hanyalah takwa kepada Allah. ${ }^{14}$

Hal ini dapat diketahui dengan cerminan praktek bermasyarakat Rosulullah di Madinah yang penuh dengan perlakuan yang humanis terhadap non-muslim. Madinah yang dibangun Rosulullah adalah negara plural, yang di dalamnya terdapat kaum Muslimin dari golongan Muhajirin dan Anshar, kaum musyrikin (pagan), dan kaum Yahudi, baik keturunan yahudi pendatang dari keturunan arab yang masuk agama yahudi atau kawin dengan orang-orang yahudi pendatang (tiga kelompok besar keturunan yahudi pendatang adalah bani Nazhir, Bani qainuqa, dan Bani Quraizhah).15

Di samping itu, penyebutan Yahudi dan Musyrikin dalam Piagam Madinah menunjukkan bahwa Rasululah saw sama sekali tidak memusuhi mereka dan juga tidak hendak membangun masyarakat politik yang ekslusf bagi orang-orang Islam, tetapi kaum non-muslim pun berhak hidup dalam masyarakat politik. Dalam Piagam Madinah disebutkan umat Yahudi yang bergabung dalam kesatuan hidup bersama kaum Muslimin berhak memperoleh perlindungan. Bahkan, di Piagam Madinah disebutkan bahwa hak dan kewajiban kaum Yahudi sama dengan warga yang tergabung dalam komunitas Madinah.

Munawir Sjadzali menegaskan, bahwa nilai dasar yang telah diletakkan oleh Piagam Madinah sebagai landasan bagi kehidupan bernegara untuk masyarakat mejemuk di Madinah adalah:

14Karim, Sejarah Pemikiran dan Peradaban Islam, h. 69-70.

${ }_{15}$ Khamami Zada and Arif R. Arafah, Diskursus Poitik Islam (Jakarta: LSIP dan Yayasan TIFA, 2004), h. 60-61. 
1) Semua pemeluk Islam, meskipun berasal dari banyak suku, tetapi merupakan satu komunitas.

2) Hubungan antara sesama anggota komunitas Islam dengan anggota komunitas-komunitas lain di dasarkan atas prinsip; (a) bertetangga baik, (b) saling membantu dalam menghadapi musuh bersama,(c) membela mereka yang teraniaya,(d) saling menasehati, dan (d) menghormati kebebasan beragama.

Satu hal yang patut dicatat, bahwa Piagam Madinah, yang oleh banyak para pakar politik didakwakan sebagai konstitusi negara Islam yang pertama itu tidak menyebut negara agama. ${ }^{16}$

Dengan demikian dapat diketahui bahwa konsep ummah dalam Piagam Madinah menurut Watt, sebagaimana dikutip oleh M. Abdul Karim adalah The Ummah is thus the complex community at Medina to which Muhammad believed himself to be sent, bahwa ummah merupakan suatu komunitas yang kompleks di Madinah. Di Madinah ini Nabi segera membangun masyarakat baru, sebuah masyarakat madani atau masyarakat sipil yang kokoh. ${ }^{17}$

\section{Unsur Politik dalam Piagam Madinah dengan Konsep ummah-nya.}

Di samping membangun masjid sebagai tempat untuk mempersatukan manusia, Rosulullah SAW juga mengambil tindakan yang sangat monumental dalam sejarah, yaitu usaha mempersaudarakan antara orang-orang Muhajir dan Anshar. ${ }^{18}$ Lebih dari itu, dalam isi perjanjian piagam madinah tersebut-sebagaimana telah dibahas dalam sub bahasan di atas-bahwasannya Nabi tidak hanya menyatukan kaum muslimin saja, melainkan juga dari kaum yang mau bersekutu dengan kaum muslimin (kaum yahudi, nasrani, dan kelompok lainnya, seperti bani an-najjar, bani 'auf, bani tsa'labah). Hal ini tidak lain adalah memiliki muatan politis bagi umat Islam, sebagai suatu komunitas yang baru dibangun. Di antara muatan politis tersebut, adalah:

\footnotetext{
${ }^{16}$ Sjadzali, Islam Dan Tata Negara: Ajaran, Sejarah, Dan Pemikiran, h. 15-16.

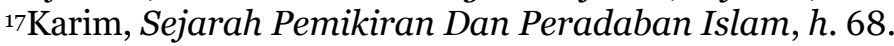

${ }^{18}$ Shafiyyur Rahman Al-Mubarakfury, Sirah Nabawiyah (Jakarta: Pustaka AlKautsar, 2004), h. 248.
} 
1) Mempersatukan kaum muslimin.

2) Melindungi kaum muslimin dari ancaman musuh.

3) Menyatukan komunitas untuk mempertahankan Islam.

\section{Negara Bangsa dalam UUD-45}

Setelah melalui berbagai persiapannya akhirnya pada tanggal 17 Agustus 1945 Bangsa Indonesia memproklamirkan kemerdekaannya serta menetapkan kepulauan nusantara ini sebagai suatu negara bangsa yang berdaulat. ${ }^{19}$

Setiap bangsa mempunyai etos atau suasana kejiwaan yang menjadi karakteristik utama bangsa itu, maka dengan sendirinya juga bangsa Indonesia. Etos itu kemudian dinyatakan dalam berbagai bentuk perwujudan seperti jatidiri, kepribadian, ideologi, dan seterusnya. Perwujudannya dalam bentuk perumusan formal yang sistematik menghasilkan ideologi, khususnya di zaman modern ini. Berkenaan dengan bangsa kita, Pancasila dapat dipandang sebagai perwujudan etos nasional kita dalam bentuk perumusan formal itu, sehingga sudah sangat lazim dan semestinya bahwa Pancasila disebut sebagai ideologi nasional. ${ }^{20}$

Ideologi Pancasila adalah final berkenaan dengan fungsinya sebagai dasar kehidupan bernegara dan bermasyarakat dalam konteks kemajemukan Indonesia. Kefinalan itu juga berkenaan dengan perumusan atau pengkalimatan formalnya sebagaimana tercantum dalam pembukaan UUD $45 \cdot{ }^{21}$

UUD 45 merupakan dasar pemerintah negara Indonesia, yangmana bangsa Indonesia sejarah pemerintahannya telah mulai sejak berlakunya UUD 1945 yang ditetapkan pada tanggal 18 Agustustus 1945. ${ }^{22}$ Adapun yang dimaksud dengan UUD 1945 itu ialah konstitusi Republik Indonesia, dalam pembukaan UUD 1945 yang ditetapkan itu berasal dari naskah rancangan pembukaan UUD (dengan perubahan) yang kemudian dikenal

19A.F Hasanuddin dkk, Pengantar Ilmu Hukum (Jakarta: UIN Jakarta Press dan Pustaka Al-Husna Baru, 2004), h. 191.

${ }^{20}$ Madjid, “Agama Dan Negara Dalam Islam: Telaah Atas Fiqh Siyasi Sunni.”, $h$. 166.

21Ibid., 178.

${ }^{22}$ C.S.T Kansil, Pengantar Ilmu Hukum Dan Tata Hukum Indonesia (Jakarta: Balai Pustaka, 1989), h.182. 
dengan nama "Piagam Jakarta" tanggal 22 Juni 1945 hasil karya panitia kecil (9 orang) dari "Badan Penyelidik Persiapan Kemerdekaan" (Dokuritsu Junbi Cosakai).

Pembukaan UUD 1945 yang terdiri dari empat alenia dan mengandung pokok-pokok pikiran yang terpenting dalamnya adalah:

a. Negara Indonesia haruslah suatu negara yang berdasarkan aliran pengertian negara kesatuan (paham unitarismus).

b. Dasar negara Indonesia yang terkenal dengan PANCASILA, yaitu;

1) Ketuhanan Yang Maha Esa

2) Kemanusiaan yang adil dan beradab

3) Persatuan Indonesia

4) Kerakyatan yang dipimpin oleh hikmat kebijaksanaan dalam permusyawaratan/ perwakilan.

5) Keadilan sosial bagi seluruh rakyat Indonesia. ${ }^{23}$

Dengan demikian, dapat ditarik suatu kesimpulan, bahwa yang dimaksud dengan Negara bangsa dalam UUD 45 (Piagam Jakarta) adalah negara kesatuan, dalam artian membentuk suatu kesatuan dari berbagai kemajemukan/ plural24--baik dari keberagaman suku, agama, budaya, bahasa-dalam satu wadah, yakni negara Republik Indonesia. ${ }^{25}$

RI juga Negara hokum. Indonesia yang merupakan Negara hukum, maka dalam pelaksanaan ketertiban aturan-aturannya juga dengan hukum yang berlaku di Indonesia. Hokum demikian dikenal dnegan hukum nasional. Hukum nasional memiliki legitimas di seluruh negeri dan dipaksakan keberlakuannya. Rakyat harus mematuhi hukum nasional

23Ibid., h. 184-185.

24 Sedangkan "pluralisme" adalah gagasan atau pandangan yang mengakui adanya hal-hal yang sifatnya banyak dan berbeda-beda (heterogen) di suatu komunitas masyarakat. Semgangat pluralisme sebagai penghargaan atas perbedaan dan heteroginitas merupakan moralitas yang harus dimiliki manusia. Terlebih-lebih di Indonesia mengingat fenomena sosio-historis, kultural, dan geografis masyarakat Indonesia sangat heteroginitas yang ditandai dengan banyaknya pulau, perbedaan adat istiadat, agama dan kebudayaan. Dalam Imam Sukardi dkk, Pilar Islam Bagi Pluralisme Modern (solo: Tiga Serangkai, 2003), h. 129.

25 Di samping dalam UUD 1945 dan Pancasila, jauh sebelum terbentuk Negara Indonesia, para pejuang "nusantara" mengingkrarkan bentuk kesatuan mereka dalam sebuah sumpah yang kemudian dikenal dengan istilah "sumpah pemuda" pada tanggal 28 Oktober 1928. 
tersebut. ${ }^{26}$

\section{E. Hubungan Piagam Madinah dengan Piagam Jakarta (UUD 1945)}

Piagam Madinah merupakan suatu bentuk konstitusi tertulis yang lahir pada komunitas yang majemuk di zaman Rosulullah, yang kemudian melatar belakangi-yang menurut para pakar politisi Islam-lahirnya negara Madinah. Relevansi Piagam Madinah ini dengan konstitusi negara Indonesia, yakni Piagam Jakarta, yang kemudian dalam perkembangannya lebih dikenal dengan UUD 1945 mempunyai kesamaan dari sisi historis dan nilai-nilai yang terkandung di dalam konstitusi keduanya. Sehingga, telaah atas keberadaan Piagam Madinah pada masa Rosulullah tersebut sudah selayaknya menjadi referensi kehidupan bernegara bagi suatu komunitas yang beragam sebagaimana di Indonesia.

Indonesia merupakan sebuah Negara kepulauan yang penduduknya sangat beragam, yang terdiri dari keberagaman suku, budaya, dan agama. Dalam sejarah panjang bangsa Indonesia, jauh sebelum lahirnya bangsa Indonesia sudah dikenal dengan istilah Nusantara, yakni pada saat kejayaan kerajaan Majapahit sebagaimana sumpah patih Gajahmada dengan Sumpah Palapa-nya yang menyatakan bahwa tidak akan memakan buah maja ketika belum bisa menyatukan nusantara. Kemajemukan bangsa Indonesia pada saat itu (kerajaan Majapahit) juga dinyatakan oleh Empu Tantular dalam kitab Sutasoma dengan kalimat "Bhinneka Tunggal Ika”.

Dengan demikian, dapat ditarik suatu kesimpulan dari persamaan antara Piagam Madinah dan Piagam Jakarta (UUD-45) dalam konsep ummah dan Negara bangsa, antara lain:

1. Dari segi historisnya, bahwa keduanya mempunyai suatu komunitas yang majemuk yang kemudian membentuk suatu komunitas yang utuh dalam satu wadah, yakni suatu negara.

2. Dari segi nilai-nilai atau pandangan hidup bermasyarakat/ bernegara,

${ }^{26} \mathrm{M}$. Nur Kholis Al Amin, "Positifikasi Hukum Islam Dalam Hukum Nasional Dalam Prespektif Filsafat Ilmu," Academy Of Education Journal. Pendidikan Pancasila dan Kewarganegaraan 4, no. 2 (2013): 94-101. 
adalah bahwa keduanya menjunjung nilai persatuan, keadilan, kesetaraan/ persamaan, dan kebebasan beragama (memegang keyakinannya).

\section{F. Kesimpulan}

Piagam Madinah merupakan suatu bentuk konstitusi dalam berdirinya institusi negara Madinah. Sehingga dalam piagam Madinah terdapat unsur substansi dalam merumuskan konsep ummah sebagai suatu komunitas yang kompleks di Madinah dan membentuk masyarakat baru yang madani, berdasarkan nilai-nilai kesetaraan, musyawarah, keadilan, dan persatuan.

Hal yang serupa dengan konstitusi Piagam Madinah dalam konteks Indonesia adalah Piagam Jakarta atau UUD 1945 (sebagai konstitusi tertinggi negara Indonesia), yang mempunyai corak persamaan dalam masalah historis ataupun nilai-nilai yang terkandung di dalamnya, yakni kemajemukan masyarakat dan prinsip-prinsip persamaan, persatuan, keadilan dalam komunitas yang satu, yakni dalam negara Indonesia. Dengan demikian, konsep negara bangsa dalam Piagam Jakarta (UUD 1945) adalah konsep yang mempunyai persamaan dengan Piagam Madinah, yakni komunitas (warga negara) yang majemuk yang hidup dalam lembaga institusi Negara Kesatuan Republik Indonesia.

\section{Daftar Pustaka}

Al-Mubarakfury, Shafiyyur Rahman. Sirah Nabawiyah. Jakarta: Pustaka Al-Kautsar, 2004.

Al Amin, M. Nur Kholis. "Positifikasi Hukum Islam Dalam Hukum Nasional Dalam Prespektif Filsafat Ilmu." Academy Of Education Journal. Pendidikan Pancasila dan Kewarganegaraan 4, no. 2 (2013): 94-101.

Al Amin, M. Nur Kholis, and Difla Nadjih. "Tinjauan Pustaka Diskursus Politik Islam.” Jurnal Ulumuddin 4, no. 2 (2014): 71-77.

Ansary, Abdou Filali. Pembaruan Islam; Dari Mana Dan Hendak Kemana? Bandung: Mizan, 2009.

Baiquni dkk, N.A. Indeks Al-Qur'an: Cara Mencari Ayat Al-Qur'an. Surabaya: Arloka, 1996.

Fatimah, Siti. Praktik Judicial Review Di Indonesia. yogyakarta: Pilar Media, 2005.

Hasanuddin dkk, A.F. Pengantar Ilmu Hukum. Jakarta: UIN Jakarta Press dan Pustaka Al-Husna Baru, 2004.

Irawan, Andrie. "Posisi Hukum Agama (Hukum Islam) Dalam Ranah Politik Indonesia." Academy Of Education Journal Pendidikan 
Pancasila dan Kewarganegaraan 6, no. 1 (2015): 65-73.

Kansil, C.S.T. Pengantar Ilmu Hukum Dan Tata Hukum Indonesia. Jakarta: Balai Pustaka, 1989.

Karim, M. Abdul. Sejarah Pemikiran Dan Peradaban Islam. yogyakarta: Pustaka Book Publisher, 2009.

Madjid, Nurcholis. "Agama Dan Negara Dalam Islam: Telaah Atas Fiqh Siyasi Sunni.” In Islam Universal. Pustaka Pelajar, 2007.

Maulana dkk, Achmad. Kamus Ilmiah Populer. yogyakarta: Absolut, 2003.

Sembodo, Cipto. "Dari Khilafah Ke Nation-States: Transformasi Hukum Islam Era Modern." Ulumuddin 6, no. 2 (2016): 136-150.

Sjadzali, Munawir. Islam Dan Tata Negara: Ajaran, Sejarah, Dan Pemikiran. Jakarta: UI-Press, 1993.

Sukardi dkk, Imam. Pilar Islam Bagi Pluralisme Modern. solo: Tiga Serangkai, 2003.

Sutiyoso, Bambang. Metode Penemuan Hukum: Upaya Mewujudkan Hukum Yang Pasti Dan Berkeadilan. yogyakarta: UII Press, 2002.

Zada, Khamami, and Arif R. Arafah. Diskursus Poitik Islam. Jakarta: LSIP dan Yayasan TIFA, 2004. 
M. Nurkholis Al-Amin \& Nurjidin 